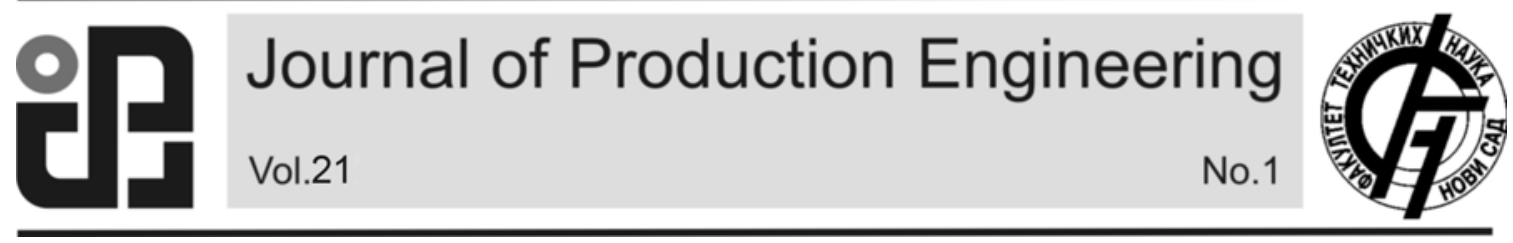

JPE (2018) Vol.21 (1)

Nguyen D. M.

Review Paper

\title{
CRITICAL SUCCESS FACTORS OF LEAN IMPLEMENTATION IN VIETNAM MANUFACTURING ENTERPRISES
}

Received: 10 May 2018 / Accepted: 20 June 2018

\begin{abstract}
Lean Manufacturing (LM) is one of the systematic approach to achieve productivity improvement for organizations. LM focuses on the wastes elimination and non-value added activities from the production. Although many enterprises succeeded in applying LM around the world, there are only less than 20 per cent of them have achieved and maintained LM activities for the time. The aim of this research is to present the critical factors constituting the successful implementation of LM in Vietnamese manufacturing enterprises. There are nine are classified as the critical for the successful adoption of LM in Vietnamese enterprises.
\end{abstract}

Key words: Lean Manufacturing, Critical success factors, Vietnamese enterprises

Kritički faktori uspeha implementacije LEAN u proizvodnim preduzećima Vietnama. LEAN proizvodnja (LM) je jedan od sistematskih pristupa za postizanje poboljšanja produktivnosti za organizacije. LM se fokusira na eliminaciju otpada $i$ aktivnosti koje nisu dodatne vrednosti iz proizvodnje. Iako su mnoga preduzeća uspela primeniti LM širom sveta, samo ih je manje od 20\% ostvarilo i održalo LM aktivnosti za to vreme. Cilj ovog istraživanja je predstaviti kritične faktore koji čine uspešnu implementaciju LM u vijetnamskim proizvodnim preduzećima. Devet je klasifikovano kao kritično za uspešno usvajanje LM u vijetnamskim preduzećima.

Ključne reči: Lean Proizvodnja, Kritički faktori uspeha, Vietnamska preduzeća

\section{INTRODUCTION}

Globalization and technologies development in the age of the fourth industrial revolution (Industry 4.0) are having enormous impacts on the manufacturing industry around the world. LM will be a standard manufacturing model in the $21^{\text {st }}$ century [1]. The strength of LM is reduce manufacturing cost through elimination all types of waste and guide a company to become a world-class organization [2]. This approach has made a substantial impact on manufacturing companies resulting in higher performance enhancements and significantly improved in productivity, quality, cost and delivery [3].

As a result, many companies have succeeded and saved millions of dollars in reducing cost via waste elimination after applied LM. However, that few companies are able to apply TPS (TPS also called as the father of LM) strategies successfully [4]. According to Kilpatrick \& Osborne, fewer than twenty per cent of the companies have succeeded in implementing LM after one year [5].

In Vietnam, LM has been known since 1990s and became a new approaching for organizations in productivity improvement, cost reduction, and quality assurance. Several Vietnamese enterprises have applied LM tools and techniques and have achieved highly encouraging results. However, LM in Vietnam is still a new concept for most of organizations. As mentioned above, the ratio of successful enterprises in Vietnam is not very high, just less than one per cent [6].

These contrasting results make LM implementation a complex and central process. Therefore, the critical success factors (CSFs) in the implementation of LM must be identified. This research aims to outline the factors that are perceived as critical for the successful application of LM.

\section{LITERATURE REVIEW}

\subsection{Lean Manufacturing}

LM is an integrated set of principles, practices, tools and techniques designed to address the root causes of operational underperformance. It is a systematic approach to eliminate the sources of loss from entire value streams in order to close the gap between actual performance and the requirements of customers and shareholders. Therefore, the objective of LM is to optimize cost, quality and delivery while improving safety. Accordingly, LM tries to eliminate three key sources of losses from the operating system: wastes, variability and inflexibility [7].

The term LM was first introduced in 1990 in the book of "The Machine That Changed the World" published by Womack \& Jones. LM is a comprehensive philosophy for structuring, operating, controlling, managing and continuously improving industrial production systems [8]. The ultimate goal of LM is the reduction of wastes in human effort, inventory, time to market and manufacturing space in order to become highly responsive to customer demand while producing world-class quality products in the most efficient and economical manner [9]. There are eight types of wastes in LM systems: Transportation, Inventory, Motion, Waiting, Over-production, Overprocessing, Defect, and Knowledge Disconnection [10] 
LM is a multi-dimensional approach that encompasses a wide variety of management practices, including Just-In-Time, JIDOKA, Standardized work, Kaizen, team work, cellular manufacturing and supplier management [11]. LM is a broad collection of principles and practices that can improve corporate performance, a manufacturing philosophy that shortens lead time and reduce costs via eliminating wastes (MUDA) yet improving quality, employee skills and job satisfaction [12]

Besides that, Nordin [13] pointed out that the ultimate goal of LM is to create a smooth, slim and high quality production to satisfy the customers' demands.

\subsection{Critical success factors}

Critical success factors (CSFs) are the limited number of factors in which satisfactory results will ensure successful competitive performance for the individual, departments or organizations. CSFs are the few areas where "things must go right" for the business to flourish and attain the manager's goals [14]. Critical success factors are very important in ensuring the successful of LM implementation and to avoid the failure risk such as creating lost to organization's costs, time and employee's efforts [15]. The CSFs approach have been widely adopted and used in a variety of different fields of study to determine key factors which are essential to the success of any program or technique. For example, Achanga [16] has classified four CSFs of Lean in SMEs, namely leadership and management, skills and expertise, finance, and culture of the continuous improvement.

\subsection{Critical success factors of $L M$ implementation}

Today, although many companies implemented LM tools and techniques, most of them are faced with challenges and difficulties. This challenges which could be avoided and overcome by identifying the CSFs of LM tools. In other words, there are many CSFs if identified and well understood that will support the overcome of these obstacles and difficulties [17]. Therefore, studying and understanding CSFs of LM implementation are very essential.

There are many papers published on CSFs with LM and productivity improvement initiatives. Table 1 below show some factors that indicated by different authors in previous researches.

\begin{tabular}{cll}
\hline \multicolumn{2}{l}{ Critical success factor } & References \\
\hline 1. & Top management involvement and commitment & {$[16,18-30]$} \\
\hline 2. & Middle management commitment & {$[26,31]$} \\
\hline 3. & Employees commitment & {$[18,21,26,32-34]$} \\
\hline 4. & Standard for evaluation and KPI & {$[18,22,24,35-37]$} \\
\hline 5. & LM training and consulting & {$[19,20,24,26,27,38,39]$} \\
\hline 6. & Culture change & {$[16,19,23-26,38]$} \\
\hline 7. & Effective communication & {$[20,22,24-26,30,38]$} \\
\hline 8. & Rewarding/Recognit-ion & {$[23,32,40]$} \\
\hline 9. & Understand tools \& techniques & {$[16,23,34,38,41,42]$} \\
\hline 10. & Linking to suppliers/vendors & {$[23,26,27,31,38]$} \\
\hline 11. & Linking to customers & {$[23,26,27,34,38,41]$} \\
\hline 12. & Flexibility and prioritization & {$[23,26,38,40,42]$}
\end{tabular}

Table 1. Synthesize Critical Success Factors for LM implementation

\section{RESEARCH METHODOLOGY}

A qualitative method has been conducted for this research to provide insights and understanding about the problems and answer "how"and "why" LM can success applied [43]. The case study method provides the flexibility for probling during interviews and gathering of in-house documentary evidence.

\begin{tabular}{|c|c|c|c|}
\hline No & Code & Years of LM applied & LM tools applied \\
\hline 1 & TMV & 20 years & $\begin{array}{l}\text { 5S, Kaizen, Visualize Management, TPM, JIT, Standardized } \\
\text { Work, Value Stream Mapping, Leveling, Takt time, SMED, } \\
\text { Andon, Poka-Yoke, Pull system, One piece Flow. }\end{array}$ \\
\hline 2 & VPIC1 & 9 years & $\begin{array}{l}\text { 5S, Kaizen, Visualize Management, Standardized Work, Kanban, } \\
\text { Pull System, Poka-Yoke }\end{array}$ \\
\hline 3 & LeGroup & 8 years & $\begin{array}{l}\text { 5S, Kaizen, Visualize Management, Standardized Work, Kanban, } \\
\text { Cell layout }\end{array}$ \\
\hline 4 & Ha Yen & 5 years & Kaizen, Kanban, FIFO, Cell layout \\
\hline 5 & Fomeco & 6 years & $\begin{array}{l}\text { 5S, Kaizen, Visualize Management, Standardized Work, SMED, } \\
\text { One piece Flow }\end{array}$ \\
\hline 6 & Disoco & 7 years & 5S,, Kaizen, Kanban, Visualize Management. \\
\hline
\end{tabular}

Table 2. Case companies profile 


\begin{tabular}{|c|c|c|c|c|}
\hline$\#$ & Case company & Top Management & Middle Management & Front line employee \\
\hline 1 & TMV & Y. Ohnoda-SMC & $\begin{array}{l}\text { N.H. Son - MA } \\
\text { N.T. Chin - GL } \\
\text { N.T. Thanh - GL }\end{array}$ & $\begin{array}{l}\text { N.T. Hai - TL } \\
\text { D.X. Thanh - TL }\end{array}$ \\
\hline 2 & VPIC1 & $\begin{array}{l}\text { M. Andy - DD } \\
\text { N.V. Bay - DGM }\end{array}$ & $\begin{array}{l}\text { D.V. Tuong - MA } \\
\text { N.V. Luc - MA } \\
\text { N.V. Tuan - MA }\end{array}$ & D.H. Ngoai - SL \\
\hline 3 & LeGroup & $\begin{array}{l}\text { L.Tuan - GD } \\
\text { L.T.N. Lan - DGD }\end{array}$ & L.T.V. Anh - MA & $\begin{array}{l}\text { N.Q. Trung - TL } \\
\text { N.T. Sau - Mbr } \\
\text { N.V. Viet - Mbr }\end{array}$ \\
\hline 4 & Ha Yen & N.T.L. Anh - GD & $\begin{array}{l}\text { N.V. Hung - MA } \\
\text { B.Q. Quyet - MA } \\
\text { P.V. Hoang - MA }\end{array}$ & $\begin{array}{l}\text { N.V. Binh - TL } \\
\text { L.H. Tu - TL }\end{array}$ \\
\hline 5 & Fomeco & H.T. Dung - DGD & $\begin{array}{l}\text { N.T. Lien - MA } \\
\text { N.T. Hanh - MA }\end{array}$ & $\begin{array}{l}\text { N.H. Hai - TL } \\
\text { N.V. Lam - TL } \\
\text { N.T. Thuc - TL }\end{array}$ \\
\hline 6 & Disoco & N.N. Khuong - DD & $\begin{array}{l}\text { N.H Viet - MA } \\
\text { V.X. Thoan - MA }\end{array}$ & $\begin{array}{l}\text { D.T. Nguyen - TL } \\
\text { L.V. Minh - SL } \\
\text { V.V. Su - SL }\end{array}$ \\
\hline
\end{tabular}

A combination technique for data collection has been employed in this research. This comprises literature review and interview key persons in LM implementation. Information from the personal interviews were conducted through prepared questionnaires. They involved a number of key personnel in the companies that included the general workforce of the concerned companies and involved in LM projects.

In order to find out perspectives companies on the factors which are critical for LM. A number of questions were tailored to enable the extraction of ideas that give a true reflection on the interviewee's perception on these factors. Preparing number of questions that embodied the companies' definition of LM and whether that company had implemented LM before. The key questions asked in the semi-structured questionnaires follow suggested by Achanga [16] as below:

- What is your definition of LM?

- What has motivated your company to implement LM?

- How many people were involved in the projects?

- What training had conducted, did the staff undertake?

- What were the difficulties and how was your team overcome?

- What were the direct and indirect resources involved in the implementation LM?

- What are the critical factors lead to success implemented? Why?

Above questions were significant for enabling the retrieval of the relevant and accurate information on lean manufacturing utilization within these companies. By asking questions about a company's major business drivers, how such a company views and perceives the concept of LM and where LM has been implemented, and at whatever resources.

\section{RESEARCH RESULTS}

After interviewed key persons listed in table 3, this research investigation has realized six key main factors that are fundamental hence critical for the implementation of LM. They include: (1) Top management involvement and direction, (2) LM culture change (3) Employee commitment, (4) Resources allocated (5) Training, education, coaching \& consulting, and (6) Measurement (KPI). In the context of LM projects implementation in Vietnam enterprises, these CSFs present the essential ingredients without which a project stands little chance of success.

In six identified factors, it has been hypothesized that factors "Top management involvement and direction" are the most critical ones in determining the success of a LM project. Strong commitment and support by daily, weekly meeting of participants is the cornerstone to the success of implementing any idea within an organization. The success of any project is first depended on top management commitment. Factor "Resources allocated" is the second critical factor for ensure successful of LM and a crucial factor in the determination of any successful project. This factor contain three main elements which are time, finance, and human resource allocation. We understand that the application of LM or any other productivity improvement initiatives within any organizations, need time, money and someone do the things. The "Organizational culture" is the third critical for the successful of LM, it is includes the core values, beliefs, norms and social customs that govern the way individuals act and behave in company. "Measurement framework", "Training, education and coaching", and "Employee commitment" are the $4^{\text {th }}, 5^{\text {th }}$, and $6^{\text {th }}$ critical factors for the successful implementation of LM in companies. The six factors listed above can be regarded as the top level of critical factors that determine for the success of LM implementation. 


\section{CONCLUSIONS}

This research has described the realization of CSFs determining a successful implementation of LM in Vietnamese manufacturing enterprises. The identified CSFs have provided useful insights for the enhancement of the critical decision making process and needed for strategy for LM application in organizations. In order to achieve the full potential of LM applications, it is important to take these factors into consideration. If any of these ingredients are missing during the implementation of LM projects, it would be then the difference between a successful implementation and a complete waste of effort, time and money. From this study it is observed that the CSFs have positive impacts on different categories of performance such as productivity, quality, delivery, and cost. Furthermore, different CSFs show different impacts on different performance criteria in different cases.

Although this research produced useful and interesting findings, there are several limitation. This study conducted in limited cases through six LM projects. In several, some factors can be a critical for enterprises but are not critical with the others, such as "Project prioritization \& selection”, "Use basic tools \& techniques first" or "Simplify procedure \& process". These factors should be analyzed in following research. The next stage of the research is needed to evaluate these factors in Vietnamese manufacturing enterprises which would enable to understand their level of importance. Future studies will also make an attempt to compare the difference ranking of the CSFs in various companies.

\section{Limitation and future research}

Case study research involves in-depth examination of one or more cases to better understand a contemporary phenomenon and extend the findings to broader theory. Multiple-case studies allow for patternmatching to be performed in order to reduce potential researcher bias and increase internal validity. However, there are some limitations in this study that restrict the generalization of the findings. For the first thing, this research is limited within the context of LEAN implementation in manufacturing enterprises, and the results can not be applicable to other sectors. The second thing, the research has conducted with a small and limited sample based mostly on the experience and memory of participants. Although representing a wide range of perspectives, a larger number of participants would lead to a more concrete multi-variant analysis. Another limitation of this research is the information sharing problems. Some persons are not very willing to provide useful information and data for the timely, futher investigation.

Futher research spanning a wider range of contingencies, in particular industry type, company size, culture, and types, mix and innovativeness of action programmes, is needed to identify whether the findings reported in this study also hold in a broader setting.

\section{REFERENCES}

[1] Rinehart, J.W., C.V. Huxley, and D. Robertson, Just another car factory?: Lean production and its discontents. 1997: Cornell University Press.

[2] Papadopoulou, T. and M. Özbayrak, Leanness: experiences from the journey to date. Journal of Manufacturing Technology Management, 2005. 16(7): p. 784-807.

[3] Fullerton, R.R. and C.S. McWatters, The production performance benefits from JIT implementation. Journal of operations management, 2001. 19(1): p. 81-96.

[4] Mácsay, V., Bányai T. , Toyota Production System in Milkrun Based In-Plant Supply. Journal of Production Engineering, 2017. 20(1): p. 141-146.

[5] Kilpatrick, J. and R. Osborne, The $R(E)$ volution of Lean. Business Breakthroughs Inc, 2006.

[6] Minh, N., Lean Management Application in Vietnam SMEs. Journal of Science-Vietnam National University, 2014. 1: p. 63.

[7] Drew, J., B. McCallum, and S. Roggenhofer, Journey to lean: making operational change stick. 2004: Springer.

[8] Detty, R.B. and J.C. Yingling, Quantifying benefits of conversion to lean manufacturing with discrete event simulation: a case study. International Journal of Production Research, 2000. 38(2): p. 429-445.

[9] Phillips, T., The production system design laboratory (PSD). 2000.

[10] Pascal, D., Lean Production Simplified - 2rd edition. 2007, New York: Priductivity Press Inc.

[11] Shah, R. and P.T. Ward, Lean manufacturing: context, practice bundles, and performance. Journal of operations management, 2003. 21(2): p. 129-149.

[12] Cook, C. and J. Graser, The effects of lean manufacturing. 2001, Santa Monica, CA: Rand Corporation.

[13] Nordin, N., B.M. Deros, and D.A. Wahab, Lean manufacturing implementation in Malaysian automotive industry: An exploratory study. Operations and Supply Chain Management, 2011. 4(1): p. 21-30.

[14] Rockart, J.F., Chief executives define their own data needs. Harvard business review, 1979. 57(2): p. 81-93.

[15] Hamid, R. Factor influencing the success of lean services implementation: conceptual framework. in International Conference on Business and Economic Research Proceeding. 2011.

[16] Achanga, P., et al., Critical success factors for lean implementation within SMEs. Journal of Manufacturing Technology Management, 2006. 17(4): p. 460-471.

[17] Skaf, K.M., Application of lean techniques for the service industry: A case study. 2007: Southern Illinois University at Carbondale.

[18] Bakås, O., T. Govaert, and H. Van Landeghem. Challenges and success factors for implementation of lean manufacturing in 
European SMES. in 13th International conference on the modern information technology in the innovation processes of the industrial enterprise (MITIP 2011). 2011. Tapir Academic Press.

[19] Leong, T.-W. and P.-L. Teh, Critical Success Factors of Six Sigma in Original Equipment Manufacturer Company in Malaysia. International Journal of Synergy and Research, 2012. 1(1): p. 7-21.

[20] Rose, A., B.M. Deros, and M.N. Ab Rahman, Critical success factors for implementing lean manufacturing in Malaysian automotive industry. Research Journal of Applied Sciences, Engineering and Technology, 2014. 8(10): p. 1191-1200.

[21] Womack, J.P., D.T. Jones, and D. Roos, Machine that changed the world. 1990: Simon and Schuster.

[22] Yang, P. and B. Yuyu, The Barriers to SMEs' Implementation of Lean Production and Counter measures----Based on SMS in Wenzhou. International Journal of Innovation, Management and Technology, 2010. 1(2): p. 220.

[23] Alhuraish, I., C. Robledo, and A. Kobi. Key Success Factors of Implementing Lean Manufacturing and Six Sigma. in Liverpool (2014): 17th Toulon-Verona Conference" Excellence in Services". 2014.

[24] Kundu, G. and B.M. Manohar, Critical success factors for implementing lean practices in it support services. International Journal for Quality research, 2012. 6(4): p. 301-312.

[25] Alaskari, O., M.M. Ahmad, and R. PinedoCuenca, Critical success factors for Lean tools and ERP systems implementation in manufacturing SMEs. International Journal of Lean Enterprise Research, 2014. 1(2): p. 183199.

[26] Kumar, M., J. Antony, and A. Douglas, Does size matter for Six Sigma implementation? Findings from the survey in UK SMEs. The TQM journal, 2009. 21(6): p. 623-635.

[27] Sabry, A., Factors critical to the success of SixSigma quality program and their influence on performance indicators in some of Lebanese hospitals. Arab Economic and Business Journal, 2014. 9(2): p. 93-114.

[28] Ab Wahid, R. and J. Corner, Critical success factors and problems in ISO 9000 maintenance. International Journal of Quality \& Reliability Management, 2011. 2(2): p. 1-13.

[29] Fiona, F. and D. Santiago, Critical Success Factors for ERP Implementation and Upgrade. Journal of Computer Information Systems (Special Issue), 2006. 99.

[30] Taner, M.T., Critical Success Factors for Six Sigma Implementation in Large-scale Turkish Construction Companies. International Review of Management and Marketing, 2013. 3(4): p. 212-225.
[31] Alaskari, O., et al., Critical successful factors (CSFs) for successful implementation of lean tools and ERP systems. 2013.

[32] Ab Wahid, R., J. Corner, and P.-L. Tan, ISO 9000 maintenance in service organisations: tales from two companies. International Journal of Quality \& Reliability Management, 2011. 28(7): p. 735-757.

[33] Kundu, G. and B.M. Manohar, Critical success factors for iplementing Lean practices in IT support services. International Journal for Quality Research, 2012. 6(4).

[34] Hibadullah, S.N., et al., Critical success factors of lean manufacturing practices for the Malaysian automotive manufacturers. International Journal of Quality and Innovation, 2014. 2(3-4): p. 256-271.

[35] Dennis, P., Lean Production simplified: A plainlanguage guide to the world's most powerful production system. 2015: CRC Press.

[36] Liker, J., The Toyota way fieldbook. 2006: Esensi.

[37] Womack, J.P. and D.T. Jones, Lean thinking: banish waste and create wealth in your corporation, revised and updated. HarperBusiness, ISBN 0-7432, 2003: p. 4927-5.

[38] Coronado, R.B. and J. Antony, Critical success factors for the successful implementation of six sigma projects in organisations. The TQM magazine, 2002. 14(2): p. 92-99.

[39] Sisson, J.A., A Framework for the Development of a Model for Successful, Sustained Lean Implementation and Improvement. 2014, University of Central Florida Orlando, Florida.

[40] Howell, M.T., Critical success factors simplified: Implementing the powerful drivers of dramatic business improvement. 2009: CRC Press.

[41] Rose, A.N.M., B.M. Deros, and M. Rahman, Critical success factors for implementing lean manufacturing in Malaysian automotive industry. Research Journal of Applied Sciences, Engineering and Technology, 2014. 8(10): p. 1191-1200.

[42] Nah, F.F.-H. and S. Delgado, Critical success factors for enterprise resource planning implementation and upgrade. Journal of Computer Information Systems, 2006. 46(5): p. 99-113.

[43] Perry, C., Processes of a case study methodology for postgraduate research in marketing. European journal of marketing, 1998. 32(9/10): p. 785-802.

Author: Nguyen Dat MINH, PhD, Electric Power University, Faculty of Industrial and Energy Management, Hanoi, Vietnam. Room No 303, M Building, No 235, Hoang Quoc Viet Street, Hanoi, Vietnam.

Phone: +84 972360032

E-mail: datminh207@gmail.com 